Article

\title{
An Evaluation of the Tourism-Induced Environmental Kuznets Curve (T-EKC) Hypothesis: Evidence from G7 Countries
}

\author{
Cem Ișik ${ }^{1, *}$, Munir Ahmad ${ }^{2}{ }^{\oplus}$, Uğur Korkut Pata $^{3}$, Serdar Ongan ${ }^{4}$, Magdalena Radulescu ${ }^{5}$, \\ Festus Fatai Adedoyin ${ }^{6}\left(\mathbb{D}\right.$, Engin Bayraktaroğlu ${ }^{1}{ }^{\mathbb{D}}$, Sezi Aydın ${ }^{1}$ and Ayse Ongan ${ }^{7}$ \\ 1 Faculty of Tourism, Anadolu University, Eskişehir 26210, Turkey; enginbayraktaroglu@anadolu.edu.tr (E.B.); \\ seziaydin@anadolu.edu.tr (S.A.) \\ 2 School of Economics, Zhejiang University, Hangzhou 310058, China; munirahmad@zju.edu.cn \\ 3 Department of Economics, Osmaniye Korkut Ata University, Osmaniye 80000, Turkey; \\ korkutpata@ktu.edu.tr \\ 4 Department of Economics, St. Mary's College of Maryland, St. Mary's City, MD 20686, USA; \\ songan@smcm.edu \\ 5 Faculty of Economic Studies and Law, University of Pitesti, 110040 Pitesti, Romania; \\ magdalena.radulescu@upit.ro \\ 6 Departament of Accounting, Economics and Finance, Bournemouth University, Fern Barrow, Poole, \\ Dorset BH12 5BB, UK; fadedoyin@bournemouth.ac.uk \\ 7 Fuqua School of Business, Duke University, Durham, NC 27708, USA; ayse.ongan@duke.edu \\ * Correspondence: cemisik@anadolu.edu.tr
}

Received: 29 September 2020; Accepted: 30 October 2020; Published: 3 November 2020

check for updates

\begin{abstract}
This paper analyzes the legitimacy of the Environmental Kuznets Curve (EKC) hypothesis for a group of seven (G7) countries over the period 1995-2015. In addition to testing the EKC speculation, the authors also would like to understand the ways in which increases in renewable energy consumption and the international tourism receipt affect the $\mathrm{CO}_{2}$ emissions in $\mathrm{G} 7$ countries, because the energy and tourism sectors may have considerable direct impacts on $\mathrm{CO}_{2}$ emissions. In this investigation, a panel bootstrap cointegration test and an augmented mean group (AMG) estimator were applied. The empirical findings indicate that the tourism-induced EKC hypothesis is valid only for France. Additionally, it was detected that a rise in renewable energy consumption has a negative (reduction) impact on $\mathrm{CO}_{2}$ emissions in France, Italy, the UK, and the US. However, an increase in the receipt of international touristm has a positive (additional) impact on Italy's CO2 emissions. Hence, this country's decision-makers should re-review their tourism policy to adopt a renewable-inclusive one for sustainable tourism and the environment.
\end{abstract}

Keywords: EKC hypothesis; tourism; G7 countries; panel bootstrap cointegration test; AMG estimator

\section{Introduction}

A rapid growth in the tourism industry mostly includes massive investments in infrastructures and superstructures [1-3]. However, the extensive tourism operations through these kinds of investments may cause several environmental problems that harm environmental sustainability [4]. Along with the expansion of the tourism industry, the consumption of natural resources poses an increased risk of environmental pollution [5]. It is expected that tourism will not only provide a source of income for countries, but also increase energy use, and thus cause $\mathrm{CO}_{2}$ emissions [6-9]. The tourism sector includes air transportation activities that require high energy use [10], and this sector was responsible for $8 \%$ of global $\mathrm{CO}_{2}$ emissions in 2013 [11]. Tourism activities require the direct use of 
fossil fuels, or indirect electricity use that is generally produced from oil, coal, and natural gas [12-15]. Therefore, the tourism industry has been accepted as one of the most energy-consuming sectors. It is also known that a high level of fossil fuel energy consumption causes an increase in $\mathrm{CO}_{2}$ emissions. However, increasing renewable energy consumption may support the environment and, thereby, support sustainable tourism-sustainable economic growth. Therefore, the tourism industry, sustainable power source utilization, and economic growth (Gross Domestic Product: GDP) may significantly impact $\mathrm{CO}_{2}$ emissions.

G7 countries are among the leading countries in terms of tourism and renewable energy. However, G7 members are the largest emitters, which are responsible for a quarter of the world's $\mathrm{CO}_{2}$ emissions [16]. Combating climate change and, therefore, reducing greenhouse gas emissions is an important priority in the agenda of G7 countries [17]. The changes in the reciept of international tourism, renewable energy consumption, per capita $\mathrm{CO}_{2}$ emissions, and per capita GDP for G7 countries are reported in Table 1 for 2005 and 2015.

Table 1. Tourism, renewable energy, pollution, and GDP in G7 countries.

\begin{tabular}{ccccccccc}
\hline G7 Countries & $\begin{array}{c}\text { The Reciept of } \\
\text { International Tourism } \\
\text { (Million US\$) }\end{array}$ & $\begin{array}{c}\text { Renewable Energy } \\
\text { Consumption (\% of } \\
\text { Total Energy) }\end{array}$ & \multicolumn{2}{c}{$\begin{array}{c}\mathbf{C O}_{\mathbf{2}} \\
\text { (MT per Capita) }\end{array}$} & \multicolumn{2}{c}{$\begin{array}{c}\text { GDP per Capita } \\
\text { (Constant 2010 US\$) }\end{array}$} \\
\cline { 2 - 9 } & $\mathbf{2 0 0 5}$ & $\mathbf{2 0 1 5}$ & $\mathbf{2 0 0 5}$ & $\mathbf{2 0 1 5}$ & $\mathbf{2 0 0 5}$ & $\mathbf{2 0 1 5}$ & $\mathbf{2 0 0 5}$ & $\mathbf{2 0 1 5}$ \\
\hline Canada & 15,887 & 16,531 & 20.2 & 22.0 & 17.4 & 15.4 & $44,471.1$ & $50,262.0$ \\
France & 52,126 & 66,441 & 8.6 & 9.40 & 6.1 & 4.6 & $40,152.7$ & $41,793.5$ \\
Germany & 40,518 & 50,669 & 6.8 & 14.2 & 9.7 & 8.9 & $38,835.4$ & $45,321.4$ \\
Italy & 15,554 & 27,285 & 6.7 & 16.5 & 8.2 & 5.3 & $37,347.6$ & $33,961.4$ \\
Japan & 38,364 & 41,415 & 3.7 & 6.3 & 9.7 & 9.2 & $44,393.6$ & $47,102.6$ \\
United & 32,948 & 50,904 & 1.4 & 8.7 & 9.0 & 6.2 & $39,984.2$ & $42,017.1$ \\
Kingdom & 122,077 & 249,183 & 5.8 & 8.7 & 19.6 & 16 & $48,499.8$ & $52,116.7$ \\
United States & \multicolumn{7}{c}{ Source: [18]. } \\
\hline
\end{tabular}

Table 1 reveals that the reciept of international tourism increased from 317,474 million USD to 502,428 million USD in ten years. This accounted for $36.1 \%$ of the global reciept of international tourism in 2015. While the highest increase in the reciept of international tourism was in the US among the $\mathrm{G} 7$, the highest growth in renewable energy consumption was in the UK. Moreover, $\mathrm{CO}_{2}$ emissions have decreased in all G7 countries. The highest decrease in per-capita $\mathrm{CO}_{2}$ emissions was in Italy. Furthermore, Italy is the only country whose per capita income decreased in the 10-year period. France, Italy, the UK, and the US are among the top 10 countries visited by the world's highest tourist numbers. Tourism in these countries can have an impact on the environment.

This paper examines the validity of the Environmental Kuznets Curve (henceforth, EKC) hypothesis for G7 countries, considering the tourism sector's impact. The theoretical origin of this hypothesis goes back to 1955. The Kuznets Curve (KC), was introduced in Kuznets (1955) [19], which conjectured an inverted U-shaped connection between economic development and income inequality. According to this hypothesis, in brief, economic growth first increases and eventually decreases income inequality over time. Following Kusnets (1955) [19], Grossman et al. (1991) [20] introduced the EKC hypothesis in the form of an environmental aspect that was inspired by the KC. According to these scholars, the initial phases of economic development lead to a deterioration in environmental quality, but after a certain point, an increase in income level, contributing to a reduction in environmental pollution. The pattern of this time-based directional relationship resembles an inverted U-shape function.

The rationale for the selection of G7 countries as the authors' sample countries is twofold. First, since these countries have already completed the industrialization process, the expectation is that the EKC hypothesis should be verified by all of the G7 countries. Second, these countries generated a total of $25 \%$ of the global $\mathrm{CO}_{2}$ emissions in 2020 [21]. All in all, G7 countries seem to be unique sample countries to examine the validity of the EKC theory. In the investigation of the EKC hypothesis, 
the authors will use the reciept of international tourism, renewable energy consumptions, and GDP as the independent variables, and $\mathrm{CO}_{2}$ emissions as the dependent variable, as shown in Table 1.

\section{Literature Review}

Although the impact of economic sectors on environmental degradation has been widely analyzed, the findings on the impact of tourism on environmental pollution are mixed [9]. Therefore, new researches and findings are needed on the tourism-environmental pollution nexus. Following Grossman et al. (1991) [20], many scholars have empirically investigated the EKC hypothesis (the inverted U-shape relationship that exists between the pollution indicators and GDP per capita) for G7 countries with different methodologies. In some of these studies, this hypothesis was verified for all of the G7 countries; in some, a few were verified; and in others, none of were verified.

In the literature review, the authors will consider only the studies that test this hypothesis specifically for the G7 countries as a group. For instance, Ajmi et al. (2015) [22] applied the time-varying Granger causality analysis for G7 countries, and didn't find the validity of the EKC hypothesis. Nabaee et al. (2015) [23] performed panel cointegration tests, and found empirical evidence of the EKC hypothesis for all of the G7 countries. However, Shahbaz et al. (2017) [24] employed various nonparametric time series methods for the G7 nations, and supported the validity of the EKC hypothesis for only six countries, namely Canada, France, Germany, Italy, the UK, and the US. Chiang et al. (2017) [25] applied the nonlinear panel smooth transition regression, and confirmed the validity of the EKC hypothesis for all of the G7 countries. Raza and Shah (2018) [26] applied the fully-modified ordinary least-squares (FMOLS) regression, the dynamic ordinary least squares (DOLS) regression, and fixed effect ordinary least squares regression for the G7 countries. They supported this hypothesis for all of the countries. Shahbaz et al. (2019) [27] applied the generalized method of moments methodology, and reached evidence of the EKC for all of the G7 countries. Yilanci and Ozgur (2019) [28] used the bootstrap panel rolling window causality test for these countries, and supported this hypothesis only for Japan and the US. Answer et al. (2020) [17] used panel random effects, and confirmed the validity of the EKC for all of the G7 countries. Ari and Senturk (2020) [29] performed various panel cointegration tests and long-term estimators, and didn't find confirmation of the EKC for any G7 country. Ike et al. (2020) [30] utilized FMOLS, DOLS, and panel mean group estimators, and reached evidence of the EKC for all of the countries. Wang et al. (2020) [31] conducted a dynamic seemingly unrelated regression method, and verified the EKC hypothesis for all seven countries.

The first part of the study provides some information about the tourism- $\mathrm{CO}_{2}$ emissions nexus and the EKC literature in G7 countries. The remainder of this study is organized as follows. Section 2 describes the model and the methodology used in the study. Section 3 provides empirical results. Finally, Section 4 concludes the paper.

This study contributes to the existing knowledge by employing a series of advanced econometric methods to analyze the EKC hypothesis in G7 countries. To this end, the cross-sectional dependence (CD) approach, the panel bootstrapping cointegration approach, and the augmented mean group (AMG) estimator were employed. In this way, it allowed the possibility of the heterogeneity of the panel for robustness purposes. The AMG estimator deals with the non-stationary variables and multifactor error terms correlated with the explanatory variables, and also considers the CD issues, which is a pre-requisite for a sound panel analysis. This study included the renewable energy consumption and tourism receipts as the independent variables in order to identify the influence of GDP on CO2 emissions, given the inclusion of those variables. Additional independent variables could be be included to test the sensitivity of the empirical findings. Additionally, the independent variables used in this study were considered and selected based on the potential most direct impacts of these variables on $\mathrm{CO} 2$ emissions based on the suggestion of the existing literature. However, this can be addressed by the future research, and can thus be taken as the limitation of this study. 


\section{Empirical Model and Methodology}

In order to test the validity of the EKC hypothesis in G7 countries from 1995 to 2015, the following model was used in regression form, as follows:

$$
\ln C O_{2 i t}=\beta_{0 i}+\beta_{1 i} \ln G D P_{i t}+\beta_{2 i}(\ln G D P)_{i t}^{2}+\beta_{3 i} \ln R E_{i t}+\beta_{4 i} \ln T_{i t}+\varepsilon_{i t}
$$

where $\mathrm{CO}_{2}$ is the carbon dioxide emissions (measured in metric tonnes per capita), GDP (constant 2000 US\$) and GDP ${ }^{2}$ are per capita real income and its square, respectively. RE is the renewable energy consumption as a percentage of the total energy, $\mathrm{T}$ is the the reciept of international tourism, and $\varepsilon$ denotes the error term. All of the factors are expressed in the logarithmic scale in order to capture long-run elasticities. The signs of $\beta_{1}$ and $\beta_{2}$ are expected to be positive and negative, respectively. This means that a rise in per capita real GDP will first lead to an increase in $\mathrm{CO}_{2}$ emissions, and then will eventually lead to a decrease in it over time. This time-based directional relation will signify the legitimacy of the EKC speculation for a nation. At the same time, the signs of $\beta_{3}$ and $\beta_{4}$ are expected to be negative and positive, respectively. This means that, while a rise in renewable energy will pioneer to decrease in $\mathrm{CO}_{2}$ emissions, a rise in the reciept of international tourism will pioneer to increase in it. The data of all of the variables were obtained from the World Bank's World Development Indicators [32], and the authors used the longest available time-series data.

In the methodology section of this study, the authors applied various cross-sectional dependence (CD) and homogeneity tests, the panel bootstrap cointegration approach introduced by Westerlund and Edgerton (2007) [33], and the augmented mean group (AMG) estimator proposed by Eberhardt and Teal (2010) [34]. The panel estimation methods that do not consider the CD and heterogeneity can lead to biased and inconsistent estimates. Therefore, the $\mathrm{CD}$ is one of the essential diagnostics that a researcher should investigate before performing a panel data analysis. Panel data can be subject to the CD (all of the units in the same-section are correlated). In order to test this, the LM CD test, given in Breusch and Pagan [35], can be applied when T $>n$ (this is the case of author's research), and a CD test can be performed when $n>\mathrm{T}$ [36], or a corrected LM test can be performed. These tests can be employed for both balanced and unbalanced panels [29]. The LM test is reliable in any event when the CD test elaborated by Pesaran (2020) [36] is not consistent. The CD can be shown in the following equation:

$$
y_{i t}=\alpha_{i}+\beta_{i} x_{i t}+\varepsilon_{i, t} ; \operatorname{cov}\left(\varepsilon_{i, t}, \varepsilon_{i, j}\right) \neq 0
$$

The null hypothesis $\left(\mathrm{H}_{0}\right)$ states that no relations exist between the cross-sections. When $n$ is fixed and $T \rightarrow \infty$, the LM statistic is fitted [34]. $\mathrm{H}_{0}$ states that the $\mathrm{t}$ statistic is asymptotically Chi-square distributed with $n(n-1) / 2$ degrees of freedom. The LM test determines the sum of the correlation coefficient squares among the cross-section residuals $(\rho i, j)$ (from OLS):

$$
\mathrm{LM}_{\mathrm{BP}}=T \sum_{i=1}^{N-1} \sum_{j=i+1}^{N} \rho_{i j}^{2}
$$

However, the Breusch-Pagan LM test statistic is not valid when $N \rightarrow \infty$. In this case, [36] developed a scaled form of the given $\mathrm{LM}_{\mathrm{BP}}$ statistic, namely, the $\mathrm{CD}_{\mathrm{LM}}$ statistics for checking the $\mathrm{CD}$. Finally, the $\mathrm{CD}_{\text {LMadj }}$ test is a modified version of the LM test (elaborated by Pesaran et al. (2008) [37]).

$$
\mathrm{LM}_{\mathrm{adj}}=\sqrt{\frac{2}{N(N-1)}} \sum_{i=1}^{N-1} \times \sum_{j=i+1}^{N} \times\left(\frac{(\mathrm{T}-\mathrm{k}) \rho_{\mathrm{ij}}^{2}-\mu \mathrm{Tij}}{v_{T i j}^{2}} .\right) ; \quad \mathrm{d} n(0,1)
$$

The exact mean of the LM adj is zero if first $T \rightarrow \infty$, and then $N \rightarrow \infty$, for many board models, including heterogeneous ground-breaking models that can present multiple breaks in their bias/skew coefficients and error variances. The problems of these models have been identified in many studies. 
The covariate-augmented Dickey-Fuller (CADF) test was elaborated by Hansen (1995) [38], who believed that the economic processes are variate or multi-dimensional. If more information is used in the unit root tests, this can increase the regression tests' efficiency and allow more concise assumptions. In order to remove the $\mathrm{CD}$, the standard ADF test is enhanced with the cross-section averages of lagged levels and the first-differences of the individual series for the CADF statistics. The CADF test is applied when $n>\mathrm{T}$, and also gives reliable results when $\mathrm{T}>n$ (this is the case in the author's research). In the CADF test proposed by Pesaran (2007) [39], the bootstrap method is not used to determine critical values. Another difference of this test is that the unit root test can be used for every panel unit and for the entire panel, which is a real advantage in the empirical analysis. A CADF test can be calculated by using the following equation:

$$
\Delta y_{i t}=a_{i}+g_{i} t+b_{i} y_{i, t-1}+c_{i} y_{t-1}+\sum_{j=0}^{p} d_{i j} \Delta y_{t-j}+\sum_{j=0}^{p} \delta_{i j} \Delta y_{i, t-j}+e_{i t}
$$

where $i=1,2,3 \ldots . t, a_{i}$ is the constant term, $t$ denotes a trend, $y_{i, t-j}$ shows lag period, and $e_{i t}$ represents the standard error term. In order to analyze the results of the CADF test for the whole panel, a cross-sectionally Im-Pesaran-Shin (CIPS) test can be applied as follows:

$$
\operatorname{CIPS}(N, T)=N^{-1} \sum_{i=1}^{N} C A D F_{i}
$$

The null hypothesis of the CADF test implies that the series have a unit root. The series' stationarity property can be analyzed by comparing the CIPS and CADF statistics with the critical values provided by Pesaran (2007) [39]. The CADF test considers dependence both inside and between the cross-sectional units, and works well in small samples, too.

The bootstrap LM cointegration test proposed by Westerlund and Edgerton (2007) [33] can be used to investigate long-run relationships. This method has good small sample properties. The LM test can provide deviations in the results in the case of $\mathrm{CD}$. The asymptotically standard normal distribution depends on the serial correlation. In order to solve this issue, the bootstrap method can be applied Ari and Senturk (2020) [29]. The autoregressive model is:

$$
\sum_{j=0}^{\infty}\left(\varphi_{i j} w_{i t-j}\right)=e_{i t}
$$

After first estimating $\varphi_{i, j}$ (the deterministic term), the authors can estimate the residuals:

$$
\hat{e}_{i t}=\sum_{j=0}^{p i}\left(\varphi_{i j} \hat{\mathrm{w}}_{i t-j}\right)
$$

The following equation was used by Westerlund and Edgerton (2007) [33] to calculate the LM statistics. In this test, the null hypothesis indicates the presence of cointegration.

$$
L M_{N}^{+}=\frac{1}{N T^{2}} \sum_{i=1}^{N} \times \sum_{i=1}^{T} \omega_{i}^{-2} S_{i t}^{2}
$$

The Augmented Mean Group ( $A M G$ ) approach allows unbiased estimations in every case of CD. The AMG estimator was elaborated by Eberhardt and Teal (2010) [34] as a substitute to Pesaran (2006) [40], the common correlated effects mean group (CCEMG) estimator. The AMG and Common Correlated Effects (CCE) estimate both the data time-series properties and the differences. A bootstrap test asserts the invalid theory of co-coordination in board data. The test considers dependence both inside and between the cross-sectional units across the panel [41]. The AMG deals with non-stationary variables and multifactor error terms, and especially considers CD. The AMG estimator's advantage 
over the CCE approach is that it deals with common unobservable variables, and treats them as a common dynamic process.

The AMG is an unbiased and efficient estimator for different values and combinations of $n$ (cross-section) and $\mathrm{T}$ (time-series) dimensions, especially when they are moderate to large. This estimator [42] is used to analysis the macro panel data in the presence of slope heterogeneity, non-stationary variables, and CD (an unobserved correlation across panel members). The coefficients on the (differenced) year's dummies represent an estimated cross-group average of the development of unobservable common factors in time across all of the countries [43]. This represents the so-called common dynamic process:

$$
y_{i t}=\beta_{i} x_{i t}+u_{i t}
$$

where $u_{i t}=\alpha_{1 \mathrm{i}}+\lambda_{i} f_{t}+\varepsilon_{i t}$ and $x_{i t}=\alpha_{2 i}+\lambda_{i} f_{t}+\gamma_{i} g_{t}+e_{i t}$, where: $i=1, \ldots n, t=1, \ldots . T, x_{i, t}, y_{i, t}$ are observable variables, $\beta_{i}=$ a country's specific slope on the observable regressors, $u_{i, t}=$ unobservable regressors, $\varepsilon_{i, t}, e_{i, t}=$ error terms (white noise), $\alpha_{1, I}=$ the fixed effects group (time-invariant heterogeneity across groups), $f_{t}, g_{t}=$ unobserved common factors that can present nonlinearity and nonstationary, and $\lambda_{i}=$ heterogenous factor loadings that expose time-variant heterogeneity and CD.

The group regression model is further enhanced with reminders of a typical powerful impact for the nation relapse. A pooled relapse upgraded with fakers is assessed by first contrast normal least squares, or with a unit coefficient (for every group member), by subtracting the estimated process from the dependent variable. The group model specifications are then averaged for the panel (weights may be applied) [43].

\section{Emprical Findings}

In order to check the $\mathrm{CD}$ among countries and the slope homogeneity, firstly, the authors applied the various tests and report results in Table 2.

Table 2. CD and heterogeneity test results.

\begin{tabular}{ccc}
\hline Test & Statistic & $p$-Value \\
\hline \multicolumn{3}{c}{ CD tests } \\
\hline $\mathrm{LM}$ & $1843.102^{\mathrm{a}}$ & 0.000 \\
$\mathrm{CD}_{\mathrm{LM}}$ & $55.107^{\mathrm{a}}$ & 0.000 \\
$\mathrm{CD}$ & $22.524^{\mathrm{a}}$ & 0.000 \\
$\mathrm{LM}_{\mathrm{adj}}$ & $13.751^{\mathrm{a}}$ & 0.000 \\
\hline \multicolumn{3}{|}{} \\
\hline$\widetilde{\Delta}$ & Heterogeneity tests & 0.000 \\
$\widetilde{\Delta}_{\text {adj }}$ & $114.531^{\text {a }}$ & 0.000 \\
\hline Note: $^{\text {a }}$ indicates statistical significance at the $1 \%$ level.
\end{tabular}

According to the test results, the null hypothesis of no CD is strongly rejected at a $1 \%$ significance level. In addition, the delta and adjusted-delta test statistics revealed the presence of slope heterogeneity. For this reason, the authors used methods that take into account the $\mathrm{CD}$ and heterogeneity in the panel data. In the next step, the authors analyzed the stationarity properties of variables using the CADF unit root test; the results are reported in Table 3.

The CADF test results show that all of the series are stationary at first differences, since the $\mathrm{t}$-statistics values of all of the panel units are lower than the critical values. In other words, the data series are integrated of the order I(1). Therefore, the long-term relationships between the series can be analyzed using cointegration tests. In this context, the authors performed the bootstrap panel cointegration test developed by Westerlund and Edgerton (2007) [33] and showed the results in Table 4. 
Table 3. CADF unit root test results.

\begin{tabular}{ccc}
\hline \multirow{2}{*}{ Variable } & \multicolumn{2}{c}{ CIPS } \\
\cline { 2 - 3 } & $\mathbf{I ( 0 )}$ & $\mathbf{I ( 1 )}$ \\
\hline $\ln \mathrm{CO}_{2}$ & -2.012 & $-2.654^{\mathrm{a}}$ \\
$\ln \mathrm{CDP}$ & -2.008 & $-2.623^{\mathrm{a}}$ \\
$(\operatorname{lnGDP})^{2}$ & -2.001 & $-2.603^{\mathrm{b}}$ \\
$\ln \mathrm{nE}$ & $-2.229^{\mathrm{b}}$ & $-3.306^{\mathrm{a}}$ \\
$\ln \mathrm{C}$ & -2.002 & $-3.295^{\mathrm{a}}$
\end{tabular}

Notes: ${ }^{\mathrm{a}}$ and ${ }^{\mathrm{b}}$ illustrate statistical significance at the $1 \%$ and $5 \%$ levels, respectively.

Table 4. Bootstrap panel cointegration test results.

\begin{tabular}{cc}
\hline LM Statistic & Bootstrap $p$-Value \\
\hline 9.433 & 0.99 \\
\hline
\end{tabular}

The results in Table 4 reveal that the null of the cointegration is validated. The LM bootstrap panel cointegration test shows the existence of a long-run association among GDP, tourism, renewable energy, GDP, and $\mathrm{CO}_{2}$ emissions. In order to estimate the long-run elasticities, the authors performed the AMG estimator. The test results of the AMG estimator are reported in Table 5.

Table 5. AMG estimation results.

\begin{tabular}{ccccc}
\hline Country & $\operatorname{lnGDP}$ & $\mathbf{( n G D P ) ^ { 2 }}$ & $\operatorname{lnRE}$ & $\operatorname{lnT}$ \\
\hline Canada & $16.754[0.90]$ & $-0.087[-0.79]$ & $-0.041[-0.10]$ & $-0.020^{\mathrm{c}}[-1.89]$ \\
France & $85.433^{\mathrm{b}}[2.29]$ & $-4.901^{\mathrm{b}}[-2.28]$ & $-0.142^{\mathrm{c}}[-1.81]$ & $0.128[1.59]$ \\
Germany & $4.451[0.22]$ & $-0.198[-0.20]$ & $-0.119[-1.45]$ & $0.014[0.18]$ \\
Italy & $56.456[1.11]$ & $-3.290[-1.10]$ & $-0.123^{\mathrm{a}}[-2.78]$ & $0.117^{\mathrm{c}}[1.88]$ \\
Japan & $-59.847[-0.58]$ & $3.103[0.59]$ & $-0.019[-0.24]$ & $-0.012[-0.36]$ \\
UK & $-26.778[-1.39]$ & $1.588[1.41]$ & $-0.088^{\mathrm{a}}[-3.29]$ & $-0.014[-0.15]$ \\
US & $-4.124[-0.20]$ & $0.302[0.22]$ & $-0.208^{\mathrm{b}}[-2.28]$ & $-0.056[-0.91]$ \\
\hline
\end{tabular}

Notes: values in brackets show t-statistics. ${ }^{\mathrm{a}},{ }^{\mathrm{b}}$ and ${ }^{\mathrm{c}}$ indicate statistical significance at the $1 \%, 5 \%$, and $10 \%$ levels, respectively.

The test findings in Table 5 show that the EKC hypothesis is verified only for France, since the coefficients of GDP and GDP ${ }^{2}$ are significantly positive and negative, respectively. This means that an upsurge in the real per capita GDP initially added to the $\mathrm{CO}_{2}$ emissions, followed by a subsequent emissions reduction in France. It aligns with the inverted U-shape association between the two variables. This result is in line with the findings of [44], who also confirmed the validity of the tourism-induced EKC hypothesis for France. The authors did not observe significant relationships between the per capita genuine GDP and per capita $\mathrm{CO}_{2}$ emissions for other countries. Furthermore, increases in RE lead to decreases in $\mathrm{CO}_{2}$ emissions in France, Italy, the UK, and the US. The most substantial negative impact (-0.208) of renewable energy on $\mathrm{CO}_{2}$ emissions was observed in the US. In regards to $\mathrm{T}$, increases in the receipt of international tourism lead to increases in $\mathrm{CO}_{2}$ emissions in Italy. More specifically, the long-run elasticities of $\mathrm{T}$ with regard to $\mathrm{CO}_{2}$ emissions is 0.117 , implying that a $1 \%$ increase in the receipt of tourism will raise the $\mathrm{CO}_{2}$ emissions by $0.117 \%$. At this point, this country's policymakers should consider this result, and maybe change the country's tourism policy somehow. These findings for Italy affirm the results of the empirical studies of Shakouri et al. (2017) [10], Tovar and Lockwood (2008) [18], Solarin (2014) [45], León et al. (2014) [46], Danish and Wang (2018) [47], and Zhang and Gao (2016) [48]. However, the authors could not detect relationships between the receipt of international tourism and $\mathrm{CO}_{2}$ emissions for other country except Canada, which had a very slight relationship intensity. 


\section{Conclusions}

This study aimed to examine the validity of the tourism-led EKC hypothesis for G7 countries. The empirical findings confirm the validity of this hypothesis only for France. This means that increases in real per capita GDP first pioneer increases in $\mathrm{CO}_{2}$ emissions, and eventually lead to decreases in it over time (shown with an inverted U-shaped relationship and pattern) [49-55].

Additionally, the authors also investigated the impacts of the tourism and energy sectors on $\mathrm{CO}_{2}$ emissions, since they dominate the G7 economies and potentially directly impact environmental quality. The authors found that the tourism sector increases $\mathrm{CO}_{2}$ emissions in Italy, while it decreases environmental degradation in Canada, with a slight impact intensity. For this reason, the policymakers of Canada must create new jobs in the tourism sector and continue to contribute to the environment with their current tourism policy. However, Italy's policymakers should review their country's tourism policy, and replace it with a sustainable one. The tourism sector in Italy dominates this country's economy. Therefore, the current tourism policy may cause millions of job losses in this country if this sector continues to pollute the environment. The non-verification of the EKC hypothesis for this country clearly shows that increases in the tourism-dominated economy (GDP) cannot reduce Italy's $\mathrm{CO}_{2}$ emissions, unlike in France.

Furthermore, the authors found that renewable energy consumption reduces $\mathrm{CO}_{2}$ emissions in France, Italy, the UK, and the US. This implies that these countries use the renewable energy sources, including solar photovoltaic energy sources, wind energy, hydro-based power production, and geothermal energy for heating systems and for the generation of electricity, or for transport electricity. The use of clean and environmentally friendly energy resources in the tourism sector should be encouraged in these countries, particularly France. For this, the cost of production and the use of renewable energy should be reduced by technological upgradation [56,57]. Renewable energy sources invested in tourism resorts can increase tourist arrivals, mainly due to their modern design or uniqueness, and could also help to create jobs [58-69]. As noted by Pata \& Terzi (2017) [70], renewable energy consumption supports economic growth in G7 countries. Therefore, a win-win strategy can be followed by increasing the economic growth and environmental quality simultaneously with incentives to use renewable resources in tourism, as well as in other sectors.

The present research estimated the EKC's validity for overall $\mathrm{CO}_{2}$ emissions; however, the sectoral calculation of $\mathrm{CO}_{2}$ emissions would provide a deep understanding of the sectoral situation of EKCs. Moreover, it would provide insights regarding the impacts of the under-analysis variables on sectoral emissions in order to target sector-specific policies. In view of this, future research may take this research as a guideline in the pursuit of further investigations in this research domain. Additionally, this research considered renewable energy consumption and the receipt of tourism as the additional independent variables. Future studies should include other determinants of $\mathrm{CO} 2$ emissions in order to check the sensitivity of the EKC's existence in response to those different variables.

Author Contributions: Conceptualization, C.I. and S.O.; methodology, C.I., S.O., and M.R.; investigation, E.B., S.A. and A.O.; writing-original draft preparation, C.I., M.A., U.K.P., S.O., M.R., F.F.A., E.B., S.A. and A.O.; writing-review and editing, C.I., M.A., U.K.P., S.O., M.R., F.F.A. and E.B.; supervision, C.I. and S.O.; project administration, C.I.; funding acquisition, Anadolu University. All authors have read and agreed to the published version of the manuscript.

Funding: This study was supported by Anadolu University Scientific Research Projects Commission, under the grant no: 2005E020.

Conflicts of Interest: The authors declare no conflict of interest.

\section{References}

1. Isik, C. The USA's international travel demand and economic growth in Turkey: A causality analysis: (1990-2008). Tour. Int. Multidiscip. J. Tour. 2012, 7, 235-252.

2. Isik, C. The importance of creating a competitive advantage and investing in information technology for modern economies: An ARDL test approach from Turkey. J. Knowl. Econ. 2013, 4, 387-405. [CrossRef] 
3. Isik, C.; Sirakaya-Turk, E.; Ongan, S. Testing the efficacy of the economic policy uncertainty index on tourism demand in USMCA: Theory and evidence. Tour. Econ. 2019. [CrossRef]

4. Ozturk, I.; Al-Mulali, U.; Saboori, B. Investigating the environmental Kuznets curve hypothesis: The role of tourism and ecological footprint. Environ. Sci. Pollut. Res. 2016, 23, 1916-1928. [CrossRef] [PubMed]

5. Mikayilov, J.I.; Mukhtarov, S.; Mammadov, J.; Azizov, M. Re-evaluating the environmental impacts of tourism: Does EKC exist? Environ. Sci. Pollut. Res. 2019, 26, 19389-19402. [CrossRef]

6. Isik, C.; Kasımatı, E.; Ongan, S. Analyzing the causalities between economic growth, financial development, international trade, tourism expenditure and/on the CO2 emissions in Greece. Energy Sourcespart B Econ. Plan. Policy 2017, 12, 665-673. [CrossRef]

7. Isik, C.; Dogru, T.; Turk, E.S. A nexus of linear and non-linear relationships between tourism demand, renewable energy consumption, and economic growth: Theory and evidence. Int. J. Tour. Res. 2018, 20, 38-49. [CrossRef]

8. Shakouri, B.; Yazdi, K.S.; Ghorchebigi, E. Does tourism development promote $\mathrm{CO}_{2}$ emissions? Anatolia 2017, 28, 444-452. [CrossRef]

9. Katircioglu, S.; Saqib, N.; Katircioglu, S.; Kilinc, C.C.; Gul, H. Estimating the effects of tourism growth on emission pollutants: Empirical evidence from a small island, Cyprus. Air Qual. Atmos. Health 2020, 13, 391-397. [CrossRef]

10. Zhang, L.; Gao, J. Exploring the effects of international tourism on China's economic growth, energy consumption and environmental pollution: Evidence from a regional panel analysis. Renew. Sustain. Energy Rev. 2016, 53, 225-234. [CrossRef]

11. Lenzen, M.; Sun, Y.Y.; Faturay, F.; Ting, Y.P.; Geschke, A.; Malik, A. The carbon footprint of global tourism. Nat. Clim. Chang. 2018, 8, 522-528. [CrossRef]

12. Paramati, S.R.; Alam, M.S.; Chen, C.F. The effects of tourism on economic growth and CO2 emissions: A comparison between developed and developing economies. J. Travel Res. 2017, 56, 712-724. [CrossRef]

13. Isik, C.; Radulescu, M. Investigation of the relationship between renewable energy, tourism receipts and economic growth in Europe. Stat. Stat. Econ. J. 2017, 97, 85-94.

14. Isik, C.; Doğan, E.; Ongan, S. Analyzing the tourism-energy-growth nexus for the top 10 most-visited countries. Economies 2017, 5, 40. [CrossRef]

15. Ongan, S.; Işik, C.; Ozdemir, D. The effects of real exchange rates and income on international tourism demand for the USA from some European Union countries. Economies 2017, 5, 51. [CrossRef]

16. Liu, M.; Ren, X.; Cheng, C.; Wang, Z. The role of globalization in $\mathrm{CO}_{2}$ emissions: A semi-parametric panel data analysis for G7. Sci. Total Environ. 2020, 718, 137379. [CrossRef]

17. Anser, M.K.; Yousaf, Z.; Nassani, A.A.; Abro, M.M.Q.; Zaman, K. International tourism, social distribution, and environmental Kuznets curve: Evidence from a panel of G-7 countries. Environ. Sci. Pollut. Res. 2020, 27, 2707-2720. [CrossRef] [PubMed]

18. World Bank. 2020. Available online: https://data.worldbank.org/ (accessed on 22 February 2020).

19. Kuznets, S. Economic growth and income inequality. Am. Econ. Rev. 1955, 45, 1-28.

20. Grossman, G.M.; Krueger, A.B. Environmental Impact of a North American Free Trade Agreement; NBER Working Paper; National Bureau of Economic Research: Cambridge, MA, USA, 1991.

21. Union of Concerned Scientists. Each Country's Share of $\mathrm{CO}_{2}$ Emissions. 2020. Available online: https: //www.ucsusa.org/resources/each-countrys-share-co2-emissions (accessed on 20 February 2020).

22. Ajmi, A.N.; Hammoudeh, S.; Nguyen, D.K.; Sato, J.R. On the relationships between CO2 emissions, energy consumption and income: The importance of time variation. Energy Econ. 2015, 49, 629-638. [CrossRef]

23. Nabaee, M.; Shakouri, G.H.; Tavakoli, O. Comparison of the relationship between $\mathrm{CO}_{2}$, energy USE, and GDP in G7 and developing countries: Is there environmental Kuznets curve for those? In Energy Systems and Management; Bilge, A.N., Toy, O.G., Mehmet, E., Eds.; Springer: New York, NY, USA, 2015; pp. $229-239$.

24. Shahbaz, M.; Shafiullah, M.; Papavassiliou, V.G.; Hammoudeh, S. The CO2 -growth nexus revisited: A nonparametric analysis for the G7 economies over nearly two centuries. Energy Econ. 2017, 65, 183-193. [CrossRef]

25. Chiang, G.; Wu, M.Y. The richer the greener: Evidence from G7 countries. Int. J. Econ. Financ. 2017, 9, 11-20. [CrossRef]

26. Raza, S.A.; Shah, N. Testing environmental Kuznets curve hypothesis in G7 countries: The role of renewable energy consumption and trade. Environ. Sci. Pollut. Res. 2018, 25, 26965-26977. [CrossRef] 
27. Shahbaz, M.; Balsalobre, D.; Shahzad, S.J.H. The influencing factors of CO2 emissions and the role of biomass energy consumption: Statistical experience from G-7 countries. Environ. Model. Assess. 2019, 24, 143-161. [CrossRef]

28. Yilanci, V.; Ozgur, O. Testing the environmental Kuznets curve for G7 countries: Evidence from a bootstrap panel causality test in rolling windows. Environ. Sci. Pollut. Res. 2019, 26, 24795-24805. [CrossRef]

29. Ari, I.; Senturk, H. The relationship between GDP and methane emissions from solid waste: A panel data analysis for the G7. Sustain. Prod. Consum. 2020, 23, 282-290. [CrossRef]

30. Ike, G.N.; Usman, O.; Alola, A.A.; Sarkodie, S.A. Environmental quality effects of income, energy prices and trade: The role of renewable energy consumption in G-7 countries. Sci. Total Environ. 2020, 721, 137813. [CrossRef] [PubMed]

31. Wang, Z.; Bui, Q.; Zhang, B.; Pham, T.L.H. Biomass energy production and its impacts on the ecological footprint: An investigation of the G7 countries. Sci. Total Environ. 2020, 743, 140741. [CrossRef]

32. World Bank. World Development Indicators. Available online: https://databank.worldbank.org/source/ world-development-indicators (accessed on 22 February 2020).

33. Westerlund, J.; Edgerton, D.L. A panel bootstrap cointegration test. Econ. Lett. 2007, 97, 185-190. [CrossRef]

34. Eberhardt, M.; Teal, F. Productivity Analysis in Global Manufacturing Production; University of Oxford: Oxford, UK, 2010.

35. Breusch, T.S.; Pagan, A.R. The lagrange multiplier test and its applications to model specification in econometrics. Rev. Econ. Stud. 1980, 47, 239-253. [CrossRef]

36. Pesaran, M.H. General diagnostic tests for cross-sectional dependence in panels. Empir. Econ. 2020. [CrossRef]

37. Pesaran, M.H.; Ullah, A.; Yamagata, T. A bias-adjusted LM test of error cross-section independence. Royal Economic Society. Econom. J. 2008, 11, 105-127. [CrossRef]

38. Hansen, B.E. Rethinking the univariate approach to unit root testing: Using covariates to increase power. Econom. Theory 1995, 11, 1148-1171. [CrossRef]

39. Pesaran, M.H. A simple panel unit root test in the presence of cross-section dependence. J. Appl. Econom. 2007, 22, 265-312. [CrossRef]

40. Pesaran, M.H. Estimation and inference in large heterogeneous panels with a multifactor error structure. Econometrica 2006, 74, 967-1012. [CrossRef]

41. Eberhardt, M.; Bond, S. Cross-Section Dependence in Nonstationary Panel Models: A Novel Estimator; Munich Personal RePEc Archive: Munich, Germany, 2009.

42. Bond, S.; Eberhardt, M. Accounting for Unobserved Heterogeneity in Panel Time Series Models; University of Oxford: Oxford, UK, 2013.

43. Eberhardt, M. Estimating panel time-series models with heterogeneous slopes. Stata J. 2012, 12, 61-71. [CrossRef]

44. Bella, G. Estimating the tourism induced environmental Kuznets curve in France. J. Sustain. Tour. 2018, 26, 2043-2052. [CrossRef]

45. Tovar, C.; Lockwood, M. Social impacts of tourism: An Australian regional case study. Int. J. Tour. Res. 2008, 10, 365-378. [CrossRef]

46. Solarin, S.A. Tourist arrivals and macroeconomic determinants of CO2 emissions in Malaysia. Anatolia 2014, 25, 228-241. [CrossRef]

47. León, C.J.; Arana, J.E.; Alemán, H.A. $\mathrm{CO}_{2}$ emissions and tourism in developed and less developed countries. Appl. Econ. Lett. 2014, 21, 1169-1173. [CrossRef]

48. Wang, D.; Wang, Z. Dynamic relationship between tourism, economic growth, and environmental quality. J. Sustain. Tour. 2018, 26, 1928-1943.

49. Farhani, S.; Ozturk, I. Causal relationship between CO 2 emissions, real GDP, energy consumption, financial development, trade openness, and urbanization in Tunisia. Environ. Sci. Pollut. Res. 2015, 22, 15663-15676. [CrossRef]

50. Isik, C.; Ongan, S.; Ozdemir, D. Testing the EKC hypothesis for ten US states: An application of heterogeneous panel estimation method. Environ. Sci. Pollut. Res. 2019, 26, 10846-10853. [CrossRef]

51. Isik, C.; Ongan, S.; Ozdemir, D. The economic growth/development and environmental degradation: Evidence from the US state-level EKC hypothesis. Environ. Sci. Pollut. Res. 2019, 26, 30772-30781. [CrossRef] 
52. Ongan, S.; Isik, C.; Ozdemir, D. Economic growth and environmental degradation: Evidence from the US case environmental Kuznets curve hypothesis with application of decomposition. J. Environ. Econ. Policy 2020, 1-8. [CrossRef]

53. Dogan, E.; Ulucak, R.; Kocak, E.; Isik, C. The use of ecological footprint in estimating the environmental kuznets curve hypothesis for BRICST by considering cross-section dependence and heterogeneity. Sci. Total Environ. 2020, 138063. [CrossRef]

54. Farhani, S.; Chaibi, A.; Rault, C. CO2 emissions, output, energy consumption, and trade in Tunisia. Econ. Model. 2014, 38, 426-434. [CrossRef]

55. Farhani, S.; Balsalobre-Lorente, D. Comparing the role of coal to other energy resources in the environmental kuznets curve of three large economies. Chin. Econ. 2020, 53, 82-120. [CrossRef]

56. Isik, C. Natural gas consumption and economic growth in Turkey: A bound test approach. Energy Syst. 2010, 441-456. [CrossRef]

57. Dogru, T.; Bulut, U.; Kocak, E.; Isik, C.; Suess, C.; Sirakaya-Turk, E. The nexus between tourism, economic growth, renewable energy consumption, and carbon dioxide emissions: Contemporary evidence from OECD countries. Environ. Sci. Pollut. Res. 2020, 27, 40930-40948. [CrossRef]

58. Isik, C.; Günlü Küçükaltan, E.; Taş, S.; Akoğul, E.; Uyrun, A.; Hajiyeva, T.; Turan, B.; Dırbo, A.; Bayraktaroğlu, E. Tourism and innovation: A literature review. J. Ekon. 2019, 1, 98-154.

59. Isik, C.; Günlü Küçükaltan, E.; Kaygalak Çelebi, S.; Çalkın, Ö.; Enser, İ.; Çelik, A. Tourism and entrepreneurship: A literature review. J. Ekon. 2019, 1,1-27.

60. Isik, C. Foreign direct investment in tourism: Panel data analysis of D7 countries. Athens J. Tour. 2015, 2, 93-103. [CrossRef]

61. Isik, C.; Shahbaz, M. Energy consumption and economic growth: A panel data aproach to OECD countries. Int. J. Energy Sci. 2015, 5, 1-5. [CrossRef]

62. Akan, Y.; Doğan, M.; Isik, C. The causality relationship between energy consumption and economic growth: The case of Turkey. Enerj. Piyas. Düzenleme 2010, 1, 101-120.

63. Akan, Y.; Arslan, I.; Isik, U.C. The impact of tourism on economic growth: The case of Turkey. J. Tour. 2008, 9, 47-69.

64. Karagöz, D.; Isik, C.; Dogru, T.; Zhang, L. Solo female travel risks, anxiety and travel intentions: Examining the moderating role of online psychological-social support. Curr. Issues Tour. 2020, 1-18. [CrossRef]

65. Günay, F.; Bayraktaroğlu, E.; Özkul, K. Assessing the short-term impacts of COVID-19 pandemic on foreign visitor's demand for Turkey: A scenario analysis. J. Ekon. 2020, 2, 80-85.

66. Halabi Kayal, M. Climate change and touristic winter activities. J. Ekon. 2020, 2, 5-7.

67. Naghizadeh, R. The study of effective factors in introduction of Ardabil markets as a tourism brand. J. Ekon. 2020, 2, 65-70.

68. Nuhanovi, A. Research on the levels of knowledge of youth in the field of energy efficiency and renewable energy sources. J. Ekon. 2021, 3, 1-4.

69. Aygün, A.; Baycan, T. A critical analysis of Turkey's tourism strategy plan (2023) based on the key factors in mitigation and adaptation to climate change. J. Tour. Leis. Hosp. 2020, 2, 48-61.

70. Pata, U.K.; Terzi, H. The relationship between renewable and nonrenewable energy consumption and economic growth in G7 countries: Evidence from bootstrap panel causality test. Acta Univ. Danub. CEconomica 2017, 13, 243-252.

Publisher's Note: MDPI stays neutral with regard to jurisdictional claims in published maps and institutional affiliations.

(C) 2020 by the authors. Licensee MDPI, Basel, Switzerland. This article is an open access article distributed under the terms and conditions of the Creative Commons Attribution (CC BY) license (http://creativecommons.org/licenses/by/4.0/). 